\title{
Transformation of Fragile Environments in the Alps and in the Sahel
}

\section{Jörg Winistörfer, Emmanuel Reynard, Lausanne}

\section{Introduction}

In the previous publication «Geography in Switzerland» in Geographica Helvetica 1980, Vol. 35, No 5, we summarised the results of research on the paleogeographical reconstruction of late glacial stages in the Valais Alps (WINISTÖRFER 1980). This field of research was the main thrust of physical geography at the University of Lausanne at the end of the 1970s and supported by «Les amis du quaternaire lémanique», a group of researchers who informally worked during ten years under the direction of Prof. emeritus M. BURRI. Research in this area dominated over two decades, resulting in two important regional studies. Dorthe-Monachon (1993) and $\mathrm{SCH}_{-}$ OENEICH (1998) reconstructed the stages of the glacier retreat in the lateral valleys on the right bank of the Rhone river and in the Ormonts, Etivaz and Hongrin valleys, respectively. In addition, AUBERT (1979) and ARN (1984) from the geology department of the University of Lausanne completed the studies of the upper and lower Rhone basin.

Currently, quaternary geomorphology and paleoclimate reconstructions are no longer an important axe of research and teaching in physical geography at the University of Lausanne. This has been replaced by four new orientations, which give more importance to the understanding of current geomorphological processes and their dynamics, and also to the interaction between the physical environment (the geomorphological environment especially) and human societies:

- The study of transformations in agricultural practices in the Sahel countries under the combined effects of environmental and socio-demographical changes;

- The study of the perception of natural hazards in alpine societies and the effects of this perception on defence strategies;

- The study of the dynamics of periglacial environments and their evolution in relation to global climate changes;

- The study of institutional management of water resources in alpine regions.

The common denominator of these four research directions is the concern for fragile environments. In the Sahel fringe, for example, environmental characteristics deteriorated drastically following the 1969-1973 and 1984-1985 droughts; in the Alps, the strong reaction of thermal regimes and the dynamics of processes involved due to recent climate change may be seen in the negative reactions of the permafrost belt. A further common concern is the fragility of the societies that live in these environments as they depend greatly on the natural processes. This is as true for rural Sahel societies, who must adapt their agricultural practices to the pluviometric situation, as it is for alpine communities, for whom the landscape is an essential factor (natural risks, natural resource management). This focus on rural or natural environments compliments the courses offered in human geography on urban environments ( $\mathrm{DA}_{\mathrm{A}}$ Cunha \& Racine, this volume).

\section{Transformation of fragile environments and the consequences}

\subsection{Agricultural practices in Sahel environments}

The Institute of Geography at the University of Lausanne (IGUL) began to develop teaching and research activities in Niger (Fig. 1) following the 1984-1985 droughts, within the framework of two programs, UNIGEO, financed by the Swiss Agency for Cooperation and Development (DEZA) and the Dean's Office of the University of Lausanne, and SPP-E (Environment and Agricultural Systems in the Sahel: dynamics, interactions and internal innovation capacities), financed by the Swiss National Science Foundation (SNF). In Burkina Faso, a program was set up to evaluate the cultivation technique of «zai» (financed by the Université Lausanne-Ecole Polytechnique Fédérale de Lausanne). This agricultural technique consists of digging holes in a field, in which the farmer puts the seeds and the manure. The technique allows manure and water to be concentrated at the base of the plant. These different projects have led to a lasting two-way scientific cooperation between the universities of Lausanne and Niamey. Since 1985, over 40 diploma theses have been completed by Swiss students in Niger.

The first publications concentrated on the characterisation of physical environments and highlighted the deterioration of natural resources (see for example, various articles in the publication edited by BRIDEL et al. 1994 and Bergoeing \& Dorthe-Monachon 1997). Attention was then focused on the rural societies and their reactions to a changing environment. Indeed, the current drop of rainfall averages, although it is not new, is the most extreme and the fastest deterioration that has occurred in the last ten thousand years (WINISTÖRFER 1998). 


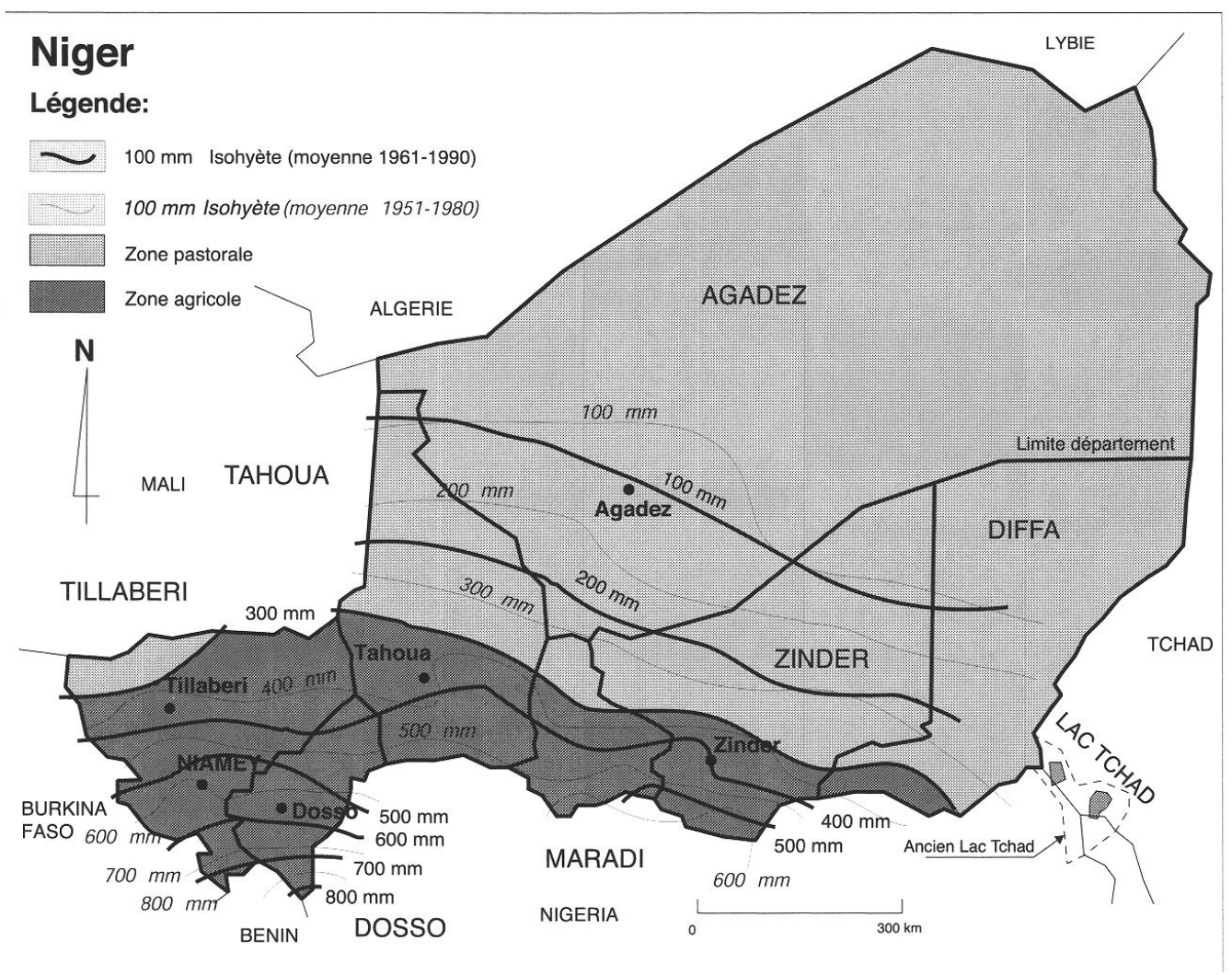

Fig. 1: Map of Niger, pluviometrical isohyetes and situation of the principal study zones. This map shows the regions which have lost about $100 \mathrm{~mm}$ of rain in the past 30 years. It is the most sensitive zone in the Sahelian region due to the fact that both population groups, i.e. farmers and herders compete for land use in the zone. Karte des Niger, pluviometrische Isohyeten und Lage der hauptsächlichen Untersuchungsgebiete. Diese Karte zeigt die Regionen, welche in den vergangenen 30 Jahren rund $100 \mathrm{~mm}$ Regen eingebüsst haben. Es ist die empfindlichste Zone der Sahel-Region aufgrund der Tatsache, dass sich Bauern und Viehzüchter in der Landnutzung in dieser Zone konkurrenzieren.

Carte du Niger, des isohyètes pluviométriques et de la situation des principales zones soumises à l'étude. Cette carte localise les régions qui ont perdu environ $100 \mathrm{~mm}$ de pluie durant les dernières 30 années écoulées. La zone la plus sensible est la région sahélienne, dans la mesure où les deux populations, les cultivateurs et les éleveurs, s'affrontent en matière d'usage du sol.

Source: Direction de la Météorologie Nationale Niamey, Niger; Cartography: G. Clivaz, Institut de Géographie, Université de Lausanne

Based on a systematic and interdisciplinary approach, our research aims to understand the different natural, economic, social and cultural dimensions of agricultural production in the current context of yield decreases, soil degradation, general drop in fertility and demographic growth, changes in the value systems, and division of production units which characterises Sahel agriculture (BAECHLER 1996). Inspired by agricultural analysis methods developed in the 1980 s, our work aims to «measure» the capacities of adaptation and the implementation of substitution strategies by the village communities when facing the transformation of their production environment.

Research carried out in the Dallol Bosso has brought to light different survival strategies used by the popu- lation in difficult periods, such as informal activities, rural exodus, commercial grazing, selling of fodder to the cities and begging. The results are a disruption of the traditional social system and the trend to sell land and traditional rights.

Another research project in the Zinder region (in the east of Niger) by WAZIRI MATO (2000) shows that, in a context marked by continuous deterioration of production conditions and an extremely hierarchical social system leaning heavily on the natural resources, the counter-season cropping around the ponds formed at the end of the rainy season diversifies the population's diet and makes up for the chronic deficit of the rainy season. This, therefore improves the population's state of health. Due to this, the ponds have an important development potential in spite of certain constraints. One of the most 
important constraints is certainly the problem of land availability as the wet areas are currently attraction poles for all actors - farmers, herders and fishermen.

More recently, in 2002/2003, in collaboration with the Geneva International Academic Network (GIAN)/ Réseau universitaire international de Genève (RUIG), the Institute engaged in a research project on water problems in three semi-arid regions: Niger, Syria and India. The Institute is primarily responsible for the research in Niger. The program deals with water and health-related questions and aims to investigate optimal water-usage under given conditions.

\subsection{Representation of natural hazards}

The National Research Program 31 (Climate Change and Natural Hazards) offered the opportunity to set up two research projects on the representation of natural risks. The first studied the representation of avalanche risk and the resulting social behaviour (population reaction, political management, and deployment of preventive measures) (Herold-Revaz et al. 1998). The second analysed the representation of various natural risks (avalanches, landslide movements, floods, foehn gales, etc.) and the resulting land occupation strategies in the Vallée des Ormonts (Vaud Pre-Alps) (Schoeneich \& Busset-Henchoz 1998). The authors showed that the popular knowledge of landslide processes and torrential phenomena was insufficient. They also showed the validity of traditional strategies (concerning land occupation or architectural adaptation), as well as the role of collective memory, which provided a sort of hazard zoning in the region studied, and constitutes therefore a non-negligible element of risk prevention. These results reflect results obtained in the Sahel concerning popular knowledge, the empirical and operational knowledge of farmers and the appropriateness of these in terms of adaptation to environmental changes (WINISTÖRFER 1996).

\subsection{Cartography and monitoring of alpine permafrost}

Several researchers at the Institute have concentrated on a third research domain over the last ten years the mapping and monitoring of alpine permafrost. This field has gained on importance in the context of current global warming. Research in this field follows different lines: mapping of the spatial distribution, characterisation of the ice content, understanding of the geomorphological processes and study of the reaction of permafrost to climate warming. Our recent research has concentrated on five study sites: Mont Gelé/Mont Fort and the Arolla regions (Valais), the Diablerets (Vaud), Creux du Van (Neuchâtel) and the region of Posets (Central Pyrenees, Spain). These studies had the following aims: mapping of permafrost distribution at a regional scale (LAMBiel \& Reynard 2001), characterisation of the ice content in periglacial envi- ronments, more precisely the glacier forefields deglaciated since the end of the Little Ice Age (REYNARD et al. 2003), study of the interaction between permafrost and avalanche barriers (PHILlips 2000), as well as study of the thermal behaviour of very low altitude sites situated well below the lower limit of discontinuous permafrost (Delaloye et al. 2003).

These different studies allow the processes taking place in permafrost zones to be better understood. We have thus been able to highlight the important role of thermal circulation for the formation and preservation of frozen bodies in scree (Delaloye et al.2003), as well as the complex relationships existing between glacial and periglacial dynamics (REYNARD et al. 2003) and between permafrost and avalanche barriers (PHILlips 2000). These different publications have also allowed us to document and better characterise the distribution of permafrost at a regional level (Fig. 2, Lambiel \& Reynard 2001).

The research in the Mont Gelé region is currently integrated in the PERMOS project (Permafrost Monitoring in Switzerland) project, whose aim is to create a permafrost observation network in the Swiss Alps (Delaloye \& Vonder MüHll 2002). Two sites studied by the Institute of Geography of the University of Lausanne (IGUL) have been monitored in this connection since 1999. Investigations of thermal behaviour at ground level and drillings have been conducted at both sites. However, our research in this area can also be seen as the investigation of natural hazard protection in connection with debris flows. Particularly for the regional authorities debris flow constitutes a serious problem. Thus, the Natural Risk Section of the Canton of Valais is partially funding a $\mathrm{PhD}$ thesis at our Institute on this topic.

\subsection{Institutional water resource management}

The Alps and mountain regions in general, are an important resource for societies, in terms of wood, landscape, water, etc. (Messerli \& Ives 1997). The most important of these resources is water. The Institute has developed over the past ten years a series of research projects focusing on water resource management in the Alps.

These studies look at the institutional aspects of water management. They concentrate on the problem of local management of common-pool resources (HARDIN 1968, Osтrom 1990), using an analysis framework specifically tailored for this purpose - institutional resource regimes (VARONE et al. 2002). The analysis of natural resource management by institutional resource regimes (IRR) entails the systematic analysis of the exploitation by man of resources in terms of goods and services. The use of these goods and services, and the management of the resources are strongly influ- 

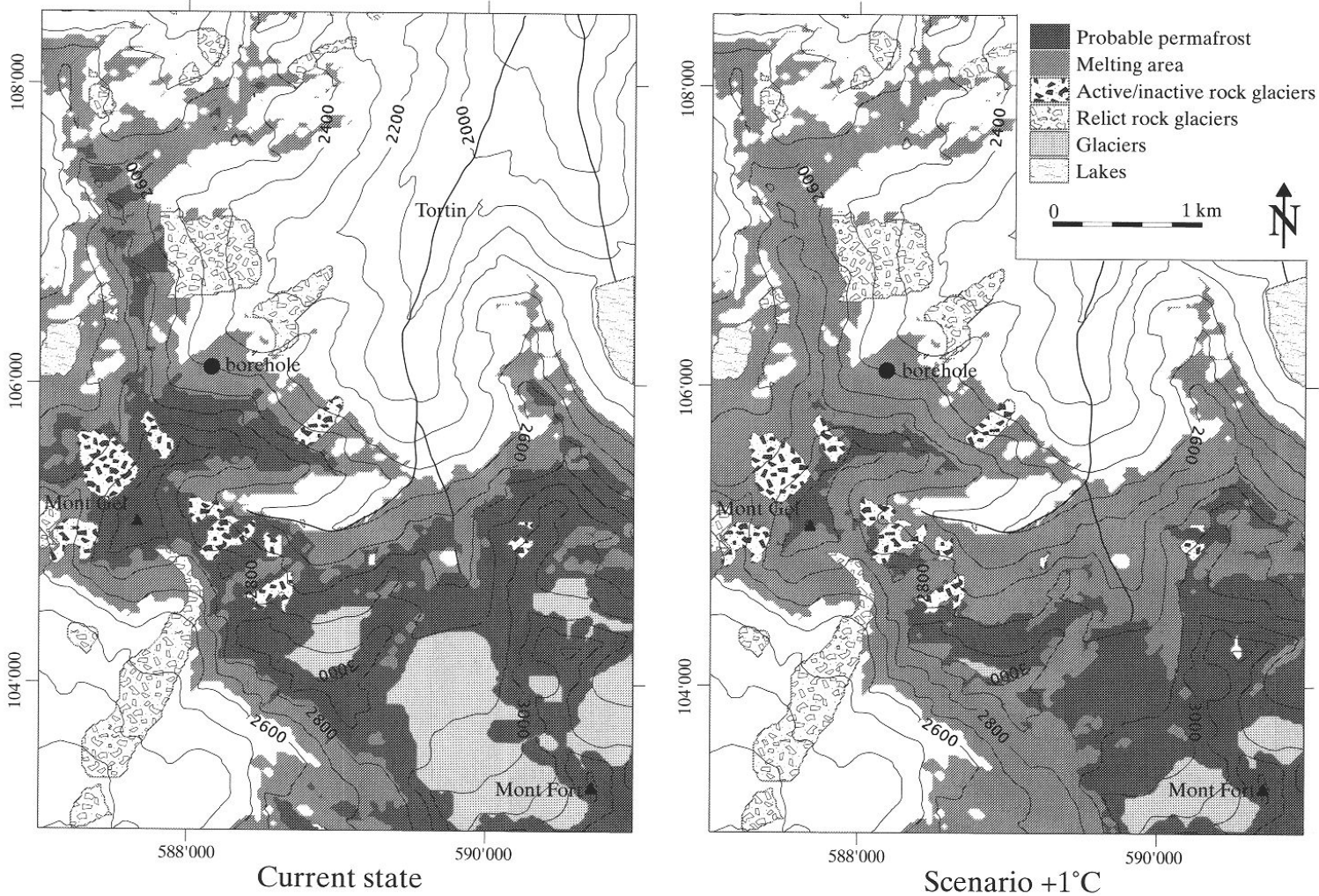

Fig. 2: Current distribution of permafrost and glaciers in the Mont Gelé (Verbier) region and projection in a context of a $1^{\circ} \mathrm{C}$ global warming.

Gegenwärtige Verteilung des Permafrosts und der Gletscher in der Region des Mont Gelé (Verbier) und Projektion in den Kontext einer Erwärmung um $1{ }^{\circ} \mathrm{C}$.

Répartition courante du permafrost et des glaciers dans la région du Mont Gelé (Verbier); projection dans un contexte d' $1{ }^{\circ} \mathrm{C}$ de réchauffement.

Source: Reprinted from «Regional modelling of present, past and future potential distribution of discontinuous permafrost based on a rock glacier inventory in the Bagnes-Heremence area (Western Swiss Alps)» by C. LAMBIEL and E. REYNARD from Norwegian Journal of Geography, 2001, 55/4, pp. 219-223, by permission of TAYLOR \& FRANCIS AS.

enced by two institutional components: property rights, already highlighted by Osтrom (1990), and public policies for the protection and exploitation of these resources. The analysis of the accompanying development of these two components of institutional regimes allows the historical evolution of water management in Switzerland to be described and qualified (VARONE et al. 2002).

Our research aims to understand the reasons of the many conflicts in local water management in various alpine valleys more precisely and to show the role played by community management associations. Thus, the goals of this research field reflect those of the Sahel research projects on agricultural environments. The studies focus mainly on two management environments: mountain tourist resorts (REYNARD 2000) and the irrigation canals in Valais, locally known as bisses. The latter is characterised by a predominant community management system of the resource (REYNARD \& BaUd 2002). Our work has notably shown the importance of historical and institutional factors (for instance, the administrative make-up) in the current water management system in Valais, a system which is neither integrated nor sustainable (REYNARD 2000). We have also shown that the community irrigation associations in Valais, which are often presented in literature as prime examples of healthy and stable institutions, are actually undergoing extreme changes due to a major agricultural depression, the demographical erosion of their members and the structural modifications that Swiss agriculture is currently being subjected to (REYNARD \& BAUD 2002). 


\section{The scientific contributions}

\subsection{Interdisciplinary research}

Most of the research currently being carried out by physical geographers at the Institute of Geography of the University of Lausanne (IGUL) is not limited to the domain of geomorphology. In all research areas, we collaborate and develop study projects with colleagues in the natural and human sciences. In periglacial environments, the technical and methodological contributions by geophysicists allowed substantial advances to be made in the question of the characterisation of ice contained in frozen ground and in the glacier forefields. In arid environments, it was only through the combination of geomorphological, earth sciences, botanical and agronomical approaches, that the impacts of agricultural practices on the evolution of the natural environment could be suitably evaluated. At the Institute, geographers collaborated with sociologists and linguists to evaluate farmers' perceptions of the environment, and in the Alps, historians, geographers and political analysts worked together to study natural risks or management of natural resources.

\subsection{Research centred on the actors}

Current research carried out by geomorphologists at the Institute constitute the traditional domains of physical geography (aridity, natural hazards, permafrost, and water resources). With the exception of the research on permafrost, all of our research projects centre on the actors involved, and less on the objects themselves. Thus, in the Sahel, the agricultural practices and their modulations under the effect of environmental transformations are studied. On the question of water resources, we focus our attention on the management institutions themselves. In the domain of natural hazards, we centre our study on the perception of risks and the resulting social behaviour.

\subsection{Research oriented toward practical application}

It is in particular in the Sahel countries that the orientation of the Lausanne research toward practical application is the most evident. In line with the research-development steps established in the 1980s, the Institute projects aim clearly at elevating the level and quality of life of the populations concerned without losing their academic nature (WAZIRI Mato 2000). Any interference in social practices must be carried out with precaution (WINISTÖRFER 1998). One of the tangible results of the relationship between the universities of Niamey and Lausanne is the establishment and development of a student counselling office in geography which, since then, has proved to be a reliable actor in a whole series of applied research in Sahel environments.

\subsection{Methodological contributions}

This resolute orientation towards interdisciplinary research also implies the development of new methodological tools. The main methodological contributions of physical geography research at the Institute concern the use of qualitative methods in the study of Sahel soil management (DorTE-MONACHON 1998) or natural alpine risks (SCHOENEICH \& BusSET-HeNCHOZ 1998). A thesis project currently being finished has developed a method of evaluation for natural reserves in Switzerland (GenTIzon 2003). In the research on periglacial environments, the systematic combination of different types of geoelectrical prospections and measurements of thermal regimes at and below the surface have allowed detailed descriptions of the study zones' characteristics to be made (e.g. Reynard et al. 2003; DelaLOYE et al. 2003).

\section{Conclusions and perspectives}

This brief presentation shows to what extent physical geography in Lausanne has renewed itself during the last twenty years. In particular, the orientation towards interdisciplinary research, and in the case of geomorphology, the focus on quantitative and dynamic research within permafrost studies, should be emphasised.

Over the next few years, the Institute aims to keep up and expand on these two approaches. This can be seen in the development of a new thrust of research, which appears to be very promising, that is of the study of geomorphological landscapes. Inserted in the greater framework of the study of landscape and the pressure human activities put on their development, the research of geomorphological landscapes requires a strong interdisciplinary approach. It requires an approach which is at the interface between geomorphology, the other natural sciences and the human sciences. From a methodological point of view, it will benefit from the competence built up over these past years by the Institute in a domain which we have not mentioned in this article, that of geomorphological mapping (Schoeneich \& Reynard 1993). A first series of results were presented during a conference on the relationships between geomorphology and tourism (REYNARD et al. 2003) that the Institute organised for the annual assembly of the Swiss Geomorphology Society. The research on this subject (in the form of a Masters thesis) is integrated into the activities of the research group titled «Geomorphological Sites: research, assessment and improvement», established for the time-span 2001-2005 by the International Association of Geomorphologists. The coordination of the research group is assured by our Institute. 


\section{References}

ARN, R. (1984): Contribution à l'étude stratigraphique du Pléistocène de la région lémanique. - Thèse de doctorat, Faculté des Sciences, Université de Lausanne.

Aubert, D. (1979): Les stades de retrait des glaciers du Haut-Valais. - Thèse de doctorat, Faculté des Sciences, Université de Lausanne.

BAECHLER, A. (éd.) (1996): Agri-cultures en mutations. - Niamey, Annales de l'Université Abdou Moumouni, Numéro hors série..

Bergoeing, J.-P. \& C. Dorthe-Monachon (1997): Etude préliminaire de la morphologie du site SaltHapex-Sahel, Niger, 1995. - Z. Geomorph. N.F., 41/4, 505-518.

Bridel L., Morel A. \& I. Ousseini (dir.) (1994): Au contact Sahara-Sahel. Milieux et sociétés du Niger. $\mathrm{N}^{\circ}$ hors-série de la Revue de Géographie Alpine, Collection Ascendances.

Da Cunha, A. \& J.-B. Racine (2003): Teaching and Research in Urban Geography at the University of Lausanne: A model at the beginning of a new century. - Geographica Helvetica 58, 3: 214-220.

Delaloye, R., Reynard, E., Lambiel, C., Marescot, L. \& R. Monnet (2003): Thermal anomaly in a cold scree slope (Creux du Van, Switzerland). - In: Phillips, M., Springman, S. \& L. Arenson (eds): Permafrost. Proceedings of the $8^{\text {th }}$ International Conference on Permafrost, Zurich, 21-25 July 2003. - Lisse: Balkema: 175-180.

Delaloye, R. \& D. Vonder Mühll (2002): Mit PERMOS Permafrost erforschen. - In: Die Alpen 10/2002: 29-32.

Dorthe-Monachon, C. (1993): Etude des stades tardiglaciaires des vallées de la rive droite du Rhône entre Loèche et Martigny. - Lausanne: Institut de Géographie, Travaux et recherches $\mathrm{n}^{\circ} 10$.

Dorthe-Monachon, C. (éd.) (1998): Méthodes pour comprendre et mesurer les pratiques agraires en milieu tropical et leurs transformations. - Lausanne: Institut de Géographie, Travaux et recherches ${ }^{\circ} 16$.

Gentizon, C. (2003): L'évaluation des réserves naturelles en Suisse. - Thèse de doctorat, Faculté des Lettres, Université de Lausanne (forthcoming).

Hardin, G. (1968): The tragedy of the commons. - In: Science 162: 1243-1248.

Herold-Revaz, A., Dulex Putallaz, S. \& L. Bridel (1998): Représentation du risque d'avalanches et comportements sociaux dans deux communes valaisannes. - Zürich: vdf Hochschulverlag.

LAMBiel, C. \& E. Reynard (2001): Regional modelling of present, past and future potential distribution of discontinuous permafrost based on a rock glacier inventory in the Bagnes-Hérémence area (Western Swiss Alps). - In: Norwegian Journal of Geography 55, 4: 219-223

Messerli, B. \& J.D. Ives (eds) (1997): Mountains of the
World. A Global Priority. - London, New York: Parthenon Publishing.

Ostrom, E. (1990): Governing the Commons:The Evolution of Institutions for Collective Action. - Cambridge: Cambridge University Press.

PHILliPs, M. (2000): Influences of snow supporting structures on the thermal regime of the ground in alpine permafrost terrain. - Davos: Eidgenössisches Institut für Schnee- und Lawinenforschung.

ReYNARD, E. (2000): Cadre institutionnel et gestion des ressources en eau dans les Alpes: deux études de cas dans des stations touristiques valaisannes. - In: Swiss Political Sciences Review 6, 1: 53-85.

Reynard, E. \& M. Baud (2002): Les consortages d'irrigation par les bisses en Valais (Suisse). Un système de gestion en mutation entre agriculture, tourisme et transformation du paysage. - In: AuвRIot, O. \& G. Jolly (dir.): Histoires d'une eau partagée. Provence, Alpes, Pyrénées. - Aix-en-Provence: Presses de l'Université de Provence: 187-212.

Reynard, E., Holzmann, C., Guex D. \& N. SummerMATTER (éds) (2002): Géomorphologie et tourisme. Lausanne: Institut de Géographie, Travaux et Recherches $n^{\circ} 24$.

Reynard, E., Lambiel, C., Delaloye, R., Devaud, G., Baron, L., Chapellier, D., Marescot, L. \& R. Monnet (2003): Glacier/permafrost relationships in forefields of small glaciers (Swiss Alps). - In: Phillips, M., Springman, S. \& L. Arenson (eds): Permafrost. - Proceedings of the $8^{\text {th }}$ International Conference on Permafrost, Zurich, 21-25 July 2003. - Lisse: Balkema: 947-952.

Schoeneich, P. (1998): Le retrait glaciaire dans les vallées des Ormonts, de l'Hongrin et de l'Etivaz (Préalpes vaudoises). - Lausanne: Institut de Géographie, Travaux et recherches $n^{\circ} 14$.

Schoeneich, P. \& E. Reynard (éds) (1993): Cartographie géomorphologique, cartographie des risques. Lausanne: Institut de Géographie, Travaux et Recherches $n^{\circ} 9$.

Schoeneich, P. \& M.-C. Busset-Henchoz (1998): Les Ormonans et les Leysenouds face aux risques naturels. - Zürich: vdf Hochschulverlag.

Varone, F., Reynard, E., Kissling-NäF I. \& C. Mauch (2002): Institutional Resource Regimes. The Case of Water in Switzerland. - Integrated Assessment 3: 78-94.

WaZIRI Mato, M. (2000): Les cultures de contre-saison dans le Sud de la région de Zinder (Niger). Lausanne: Institut de Géographie, Travaux et Recherches $n^{\circ} 15$.

WINISTÖRFER, J. (1980): Late pleistocene and holocene glacier extents in the Alps of Central Valais. - In: Geographica Helvetica 35, 5: 53-56.

WINISTÖRFER, J. (1996): Recherche universitaire et développement. Apports d'une recherche interdisciplinaire dans le développement. - In: Agri-cultures 
en mutations, Niamey: Annales de l'Université Abdou Moumouni: 17-24.

WinISTÖRFER, J. (1998): Une géographie pour le Sahel, point de vue du géographe du Nord. - In: Méthodes pour comprendre et mesurer les pratiques agraires en milieu tropical et leurs transformations. - Lausanne: Institut de Géographie, Travaux et recherches $n^{\circ} 16$ : 3-7.

Prof. Dr. Jörg Winistörfer, Dr. Emmanuel Reynard, Institut de Géographie, Université de Lausanne, BFSH 2, CH-1015 Lausanne.

\section{Internet address}

Institut de Géographie de l'Université de Lausanne: http://www.unil.ch/igul/ 